\title{
Mobile Phones in Classrooms and in Professor-Student Communication: Ukrainian, Omani, and U.S. American College Students' Perceptions and Practices
}

\author{
https://doi.org/10.3991/ijim.v15i10.21757 \\ Alla V. Tovares $(\bowtie)$ \\ Howard University, Washington DC, USA \\ atovares@howard.edu \\ Cynthia Gordon \\ Georgetown University, Washington DC, USA \\ Najma Al Zidjaly \\ Sultan Qaboos University, Muscat, Oman
}

\begin{abstract}
The unprecedented expansion of wireless technologies and the global pandemic of 2020-2021, which forced many educational establishments out of traditional face-to-face and into online instructional environments, have created an urgency for achieving a better understanding of the various education-related uses of mobile phones, and students' attitudes toward them, worldwide. We conducted a questionnaire-based study to explore college undergraduate students' perceptions and uses of mobile phones, with a focus on instructor-student communication and classroom use, across three diverse cultural contexts: Ukraine, Oman, and the United States. Based on our findings, we suggest that conceptualizing mobile phones as cultural tools and situating their use within cultural discourses illuminates how - and explains why - mobile phones are not "the same" tools for all students. The findings offer insights into students' (developing) perspectives on uses of mobile phones, and provide grounds from which to formulate productive, and culturally appropriate, means of using them for educational purposes.
\end{abstract}

Keywords-Mobile phones; professor-student communication; m-teaching and learning; cultural tools and discourses

\section{Introduction}

The COVID-19 pandemic, in forcing educational institutions worldwide to switch to online modes of instruction, not only has brought into sharp relief differences between face-to-face and online teaching and learning, but also has renewed the importance of a nuanced, context-specific understanding of students' uses and perceptions of new communication technology, notably their seemingly omnipresent mobile phones. This study offers a snapshot of college students' perceptions and reported 
uses of mobile phones, with a focus on instructor communication and classroom settings, in Ukraine, Oman, and the United States. Analyzing survey data we collected in 2012-2014, we advance the idea that mobile phones are productively conceptualized, by both instructors and researchers, as "cultural tools" [1] that only make sense in the context of specific "cultural discourses" [2]. This understanding provides the groundwork for the development of culturally appropriate practices regarding uses of phones for teaching and learning.

Mobile technologies are constantly evolving and their reach and role in society are rapidly expanding. In 2013, around our time of data collection, the number of mobile phone service subscriptions was almost equal to the entire world population [3]. The latest report by the International Telecommunication Union estimates that worldwide there are 105 mobile phone subscriptions per 100 inhabitants [4]. The unprecedented expansion of wireless technologies and of their roles in people's lives has led to everincreasing interest among researchers. While initially many research projects, including our own [5,6], largely focused on social uses of mobile phones, investigations into the place of mobile phones in educational settings have been gaining momentum (e.g., see [3, 7-12]), ranging from students' attitudes toward them in Jordan [7], uses of them in lectures in Australia [8], and ethical concerns about them in Myanmar [9]. The global pandemic of 2020, which continues into 2021, forced many educational establishments out of traditional face-to-face and into online instructional environments. This increases the importance of better understanding how students perceive their mobile phones as resources for (virtual) learning worldwide.

In 2008, Godwin-Jones [13] observed that as smartphones became more affordable and pervasive, they came to be seen as important tools in mobile learning (mlearning). However, recent studies $[10,14,15]$ have noted that mobile phones' uses in educational environments remain understudied. While researchers $[16,17,18]$ remark that there is much to be learned about the effectiveness of small mobile technologies in education, educators and administrators raise concerns about the costs required to deploy and maintain such technologies and their reported negative effects (e.g., increasing instances of student cheating and distraction). Furthermore, as Tossell and colleagues [3] note, the initial enthusiasm and excitement associated with the educational possibilities of mobile technology, mobile phones in particular, have been "tempered by the realization that social and educational smartphone uses are different," which requires attentiveness to contextual differences (p. 714). In 2020, Williamson, Eynon, and Potter [19] warned that - in the context of COVID-19 and beyond - it would be simplistic, and detrimental, to view educational technologies as ready-made and one-size-fits-all, and the authors call for their rigorous (re)evaluation. In sum, more research is needed to achieve nuanced understandings of how mobile phones can be used as effective teaching and learning tools.

Building on our previous research highlighting the relationship between mobile phones and young adults' identities $[5,6]$, we investigate students' perceptions and uses of mobile phones as reported by undergraduate students we surveyed. Drawing on Scollon's [1] concept of "cultural tools," we propose that mobile phones are best understood as material means or tools that have affordances, constraints, and histories that are embedded in sociocultural contexts. Our analysis also integrates Carbaugh's 
[2] notion of "cultural discourses," which captures the idea that culturally-shaped ideologies about personhood, relationships, and communication shape everyday practices. Conceptualizing mobile phones as cultural tools, and situating their use within cultural discourses, enhances our ability to understand how people of various cultural backgrounds orient to and use them, and in turn shape them, thus illuminating the roles mobile phones play for different students in different cultural and educational contexts and at different moments in time. Identifying such differences circumvents possible issues of intercultural miscommunication in educational and other institutional settings wherein mobile phones are present, while also providing guidance for how educators might use mobile phones more effectively. In our earlier work based on part of the same larger dataset from which we draw our data here [6], we suggested that understanding mobile phones as cultural tools enables researchers "to explain not only how they are treated differently in different cultural groups, but also the specific linkages they have to various aspects of identity in each group" (p. 14). In this study, we continue exploring how mobile phones are appropriated as cultural tools in different national cultural contexts by uncovering student perceptions of their roles and uses in college classrooms in three countries - the post-Soviet Eastern European country of Ukraine, the Islamic social monarchy of Oman, and the United States - two of which represent relatively understudied contexts for mobile phone use (Ukraine and Oman). In what follows, we first briefly provide additional background and then describe our data and methods. This is followed by the presentation of our findings. In the discussion, we emphasize implications of our study, identify limitations, and offer concluding remarks in which we summarize our findings and suggest directions for future research.

\section{Background}

Extant literature has begun to address some of the many complex questions that are related to uses of mobile phones in classroom settings and for m-learning in general. For instance, Tossell and colleagues [3], who studied U.S. American undergraduate students' perceptions and uses of iPhones in class, report that prior to receiving and using their phones, the students viewed the iPhone as an educational asset that would help improve their grades. However, just a year later students in the study had changed their perceptions and expectations, labeling the iPhone as "a distraction and a competitor to requisite learning for classroom performance" (p. 713). Put differently, the students overestimated the educational potential of the iPhone and underestimated how much of a distraction it could be. These authors suggest that their results are compatible with prior studies (e.g., $[21,22])$ that link interruptions and distractions to "disjointed activity [that] has been shown to be unfavorable to learning" (p. 722). Of interest, only $3 \%$ of the installed applications on students' iPhones were educational while games were most frequently installed (p. 718). Tugun and colleagues' [12] survey of 75 university students during academic year 2019-2020 in Russia revealed that gameplay was a relatively commonly reported use of technology (by 18 students), which lags far behind a broad category the authors labeled as "communication" (re- 
ported by 45 students), but well ahead of searching for information (reported by 10) and preparing homework (reported by 2). Al Fakih, Morei, and Salehi's [11] recent survey of 392 students at a university in Qatar found that students by a small margin favored the use of mobile phones in classrooms; students who disfavored their use reported them to be distracting. While the number one reported use of phones in classrooms was to register attendance, the second most identified use differed by gender: recording lectures for women, and making urgent phone calls for men. Such findings demonstrate that having access to mobile technology does not automatically translate into improved educational outcomes nor does it guarantee productive use for educational purposes; further, different students use mobile technologies differently.

At the same time, Keengwe, Schnellert, and Jonas [15] observe that educators need to recognize that digital devices can "engage, enable, and empower" (p. 441) young learners for many of whom mobile phones are inextricable, and indispensable, parts of their social lives [22, 23] and even their bodies [24]. Some researchers have even conceptualized young people's attachment to their mobile phones as a type of addiction [25] or anxiety disorder [11]. What is indisputable is that mobile phones are omnipresent in most societies, especially among younger generations. This has led some researchers (e.g., $[26,27])$ to suggest that educators should take into consideration their students' familiarity with and reliance on mobile technology to find ways to incorporate such technology into teaching and learning. For example, Domínguez and colleagues [28], whose study was carried out in the United States, suggest that using game design elements in educational contexts may increase student engagement. Their findings, however, indicate that while "the gamified experience" improved students' scores on some assignments, their participation in class activities decreased as did their written assignment scores. Similar to Tossell and coauthors [3], the researchers indicate that the students' initial motivation for using m-technology did not translate into overall educational success. Related, a study of the use of smartphone clicker apps among Saudi male undergraduate students shows that the increased interactivity in class did not improve the overall level of student engagement in the learning activity [29].

This reported mismatch between expectations and outcomes of using mobile phones in class and between how students and educators view mobile phones is addressed by Keengwe and colleagues [15] who write that "while proponents of mobile phones view them as a potential learning tool for online resources, communication, and multi-media creativity, many school leaders only see them as a hindrance to meaningful learning especially considering their host of likely distractions from student ring tones, e-mails, texting, tweeting, and cheating." Students too worry about issues such as cheating [9]. In addition, Sad and Göktas [30] indicate that while "the world is becoming a mobidigital [mobile and digital] virtual space where people can learn and teach digitally anywhere" and mobile device use is ubiquitous among students, teachers are often not up-to-speed with new technologies and are apprehensive about their use in class (p. 606; for a related idea, see [31]). For instance, Sad and Göktas find that preservice teachers in Turkey privilege laptops over mobile phones as educational tools. However, smartphones are omnipresent on many college campuses, so their existing roles as well as their instructional and learning potential can- 
not be ignored. Corrin, Lockyer, and Bennett's [32] questionnaire-based study among students at an Australian university identifies mobile phones as one of many communication technologies students use for educational purposes, but also finds that usage rates of such technologies tend to be lower there than in everyday social life. Their findings also indicate that students use their mobile phones for calling and texting for educational purposes, but do not specify with whom students are communicating (it could be their peers). Somewhat in contrast, Roberts and Rees [8] find that students at a university in Australia used mobile phones in class mostly for off-task activities. Finally, it is important to point out that students' (and educators') access to hardware (smartphones) and software (apps) is not the same worldwide. For instance, as Nami [33] remarks, Iranian students cannot purchase apps from Western developers due to sanctions.

Collectively, these studies suggest that exploring mobile phone use on college campuses and in classes without taking into consideration larger sociocultural contexts can result in an incomplete picture. Prior studies [22, 34, 35], including our own $[5,6]$, suggest that mobile phones are not only means of electronic communication but are also linked to users' identities. In this sense, understanding what a phone means for an individual person, and in the wider sociocultural context, becomes important. The COVID-19 pandemic has brought to the fore many of the aforementioned issues, including professors' varying competencies regarding integrating communication technologies into their teaching, struggles to create community via screens, and other challenges such as managing cheating, asynchronous discussions, "Zoom fatigue," and the posting of offensive material in online learning contexts (sometimes known as "Zoombombing"), as is evident in perusing articles and essays published in academic venues, such as Chronicle of Higher Education [36] and Inside Higher Ed [37], as well as in the news media, such as The Guardian [38]. While we conducted our survey among college students before the pandemic, our findings demonstrate the diversity of perspectives of those whose thoughts and experiences are perhaps of most value when it comes to mobile phones and education - the learners and suggest that these perspectives should be regularly revisited in the context of cultural change.

\section{Data and Methods}

To gain a better understanding of student perceptions and uses of mobile phones in both academic and social lives of undergraduate students in Oman, Ukraine, and the United States, we constructed a questionnaire based on prior work on mobile phones and on our ethnographic observations in each country. Because we had connections to and great familiarity with educational institutions in the aforementioned countries (thus, the student-participants represent a convenience sample), we distributed paper copies of the questionnaire - in Arabic, Ukrainian, and English - targeting first-year college students. While paper questionnaires are cumbersome, they provided equal access for all student-participants because during data collection (2012-2014), not all classrooms, especially in Ukraine, had online access nor did all students have 
smartphones or personal computers/tablets. Omani participants were students at Sultan Qaboos University, the national university of Oman; Ukrainian students were enrolled at a national university in Western Ukraine, and U.S. American students (who we will henceforth abbreviate as "American students") were attending a private university in the Northeastern United States. Table 1 summarizes the data set, including the period of data collection, the number of student-participants, and their fields of study.

Table 1. Study participants by country and gender (adapted from [6])

\begin{tabular}{|l|l|c|c|c|l|}
\hline & \multicolumn{1}{|}{$\begin{array}{c}\text { Year(s) of data } \\
\text { collection }\end{array}$} & $\begin{array}{c}\text { Total Parti- } \\
\text { cipants }\end{array}$ & $\begin{array}{c}\text { Female parti- } \\
\text { cipants }\end{array}$ & $\begin{array}{c}\text { Male Parti- } \\
\text { cipants }\end{array}$ & $\begin{array}{c}\text { Participants' } \\
\text { major field } \\
\text { of study }\end{array}$ \\
\hline Oman & Spring 2014 & 150 & 100 & 50 & $\begin{array}{l}\text { Arts and Social } \\
\text { Sciences }\end{array}$ \\
\hline Ukraine & Spring 2013 & 100 & 83 & 17 & Humanities \\
\hline United States & Fall 2012; Fall 2014 & 143 & 95 & 48 & Communication Studies \\
\hline TOTAL & & 393 & 278 & 115 & \\
\hline
\end{tabular}

As we note elsewhere [6], while our data set allowed us to explore reported uses and perceptions of mobile phones among college students across three cultural contexts, it is not exhaustive or all-inclusive. For example, only "male" and "female" were used as choices for gender designations; participants' race/ethnicity selfidentifications (notions that are especially pertinent in the U.S. context) were not collected. Additionally, our samples across the different countries were different. For instance, men were underrepresented in the Ukrainian subset, mainly owing to the fact that at the time of data collection over $76 \%$ of the students in the humanities and social sciences in Ukraine were women [39]. Nonetheless, our findings - preceding the present moment (and the pandemic) - represent a snapshot view of students' evolving relationships with mobile phones, their understandings of how their phones fit into their academic lives, and how their perspectives are culturally influenced.

We constructed the questionnaire collaboratively, based on existing literature and ethnographic observations. First, the questions were formulated in English, then translated into Arabic by Al Zidjaly's research assistant and into Ukrainian by Tovares. The questionnaire mainly used a Likert scale, but it also had several open-ended questions. The Likert scale-based questions asked the student-respondents to choose from the following options: "strongly agree," "agree," "neither agree nor disagree," "disagree," and "strongly disagree." Because of a relatively small data sample and for the ease of reference and exposition, we - following other studies (e.g., [40]) - collapsed the aforementioned options into three categories: "strongly agree/agree" (which we shorten to AGREE), "neither agree nor disagree" (NEUTRAL), and "disagree/strongly disagree" (DISAGREE). Skipped questions were recorded as NO RESPONSE. To show distinct patterns and because most responses fell into AGREE and DISAGREE categories, in this paper we focus on these types of responses. Additionally, and in line with Bell's [41] argument that cultural contexts affect people's relationships to new communication technologies, we interpreted our questionnaire findings in the context of the ethnographic observations we each undertook in our 
native countries. In our earlier work [6], we discussed findings related to mobile phones as objects for self-expression, tools for identity construction, and resources for establishing and maintaining familial and interpersonal relationships. In that work, as here, we follow Scollon [1] in conceptualizing mobile phones as "cultural tools," and we consider such tools in light of what Carbaugh [2] refers to as "cultural discourses." Put differently, mobile phones are cultural tools, or material objects, that have histories and enable certain social actions (i.e., have affordances) while restraining others (i.e., have limitations) and are situated in ideologies that circulate among members of a cultural group about communication, relationships, and personhood. In what follows, we present the results of the part of the questionnaire that focused on students' perceptions and uses of mobile phones as related to education, putting our findings into dialogue with those regarding uses of phones in the context of their personal relationships. Our discussion of each of the findings takes a cultural tools/cultural discourses perspective.

\section{$4 \quad$ Results and Discussion}

\subsection{Mobile phones as devices for creating connection}

A clear pattern across the Ukrainian, Omani, and American samples is that college students viewed their mobile phones as tools for connection. However, with whom they use their phones to connect varies. Across all groups, mobile phones are seen as means to connect with family members and friends; groups vary, however, regarding views about mobile phones and connecting with professors (as well as romantic partners, which we briefly discuss to give a fuller picture and advance the cultural tools perspective) (Table 2). American students (especially) and Ukrainian students reported using mobile phones to connect with romantic partners to lower degrees than to family and friends. This finding might have resulted from a lack of romantic involvement among first-year-students; for example, one female Ukrainian student wrote on her questionnaire: "У мене немає хлопця!!/I do not have a boyfriend!!" While most American and Ukrainian students viewed their mobile phones as a resource for connecting with a (potential) romantic partner, the situation is different in Oman because private interactions between members of the opposite sex outside family are culturally discouraged, even prohibited. It is thus notable that a rather high percentage of respondents (72\%) indicated that they use their mobile phones to connect with a "friend of the opposite sex," (the culturally-appropriate, though unfortunately heteronormative term we used in place of "romantic partner"). Omani students thus appear to use mobile phones to create new spaces and relationships, challenging and expanding cultural norms (see [5] for a related discussion). 
Table 2. I use my mobile phone to connect with my...

\begin{tabular}{|c|c|c|c|}
\hline \multicolumn{2}{|c|}{ Family members } & \multicolumn{2}{|c|}{$\begin{array}{l}\text { Boyfriend/girlfriend (Friend of the opposite sex } \\
\text { in Omani questionnaire) }\end{array}$} \\
\hline Agree & Disagree & Agree & Disagree \\
\hline \multicolumn{2}{|c|}{ American college students } & \multicolumn{2}{|c|}{ American college students } \\
\hline $97 \%$ & $2 \%$ & $64 \%$ & $27 \%$ \\
\hline \multicolumn{2}{|c|}{ Ukrainian college students } & \multicolumn{2}{|c|}{ Ukrainian college students } \\
\hline $78 \%$ & $8 \%$ & $73 \%$ & $16 \%$ \\
\hline \multicolumn{2}{|c|}{ Omani college students } & \multicolumn{2}{|c|}{ Omani college students } \\
\hline $72 \%$ & $4 \%$ & $72 \%$ & $2 \%$ \\
\hline \multicolumn{2}{|c|}{ Friends } & \multicolumn{2}{|c|}{ Professors } \\
\hline \multicolumn{2}{|c|}{ American college students } & \multicolumn{2}{|c|}{ American college students } \\
\hline $97 \%$ & $3 \%$ & $8 \%$ & $77 \%$ \\
\hline \multicolumn{2}{|c|}{ Ukrainian college students } & \multicolumn{2}{|c|}{ Ukrainian college students } \\
\hline $78 \%$ & $10 \%$ & $13 \%$ & $63 \%$ \\
\hline \multicolumn{2}{|c|}{ Omani college students } & \multicolumn{2}{|c|}{ Omani college students } \\
\hline $79 \%$ & $1 \%$ & $\begin{array}{c}41 \% \\
45 \% \text { (women) } \\
35 \% \text { (men) }\end{array}$ & $\begin{array}{c}16 \% \\
20 \% \text { (women) } \\
10 \% \text { (men) }\end{array}$ \\
\hline
\end{tabular}

In contrast to the relative similarities in how students in Ukraine, Oman, and the U.S. report using phones to connect with family members, friends, and romantic partners/members of the opposite sex, only $8 \%$ of participating American and $13 \%$ of Ukrainian students (with not much difference between male and female students) reported using their mobile phones to connect with their professors. This finding supports previous research that has identified and investigated mobile phones [42] and computer- and smart-phone based applications like Facebook [43] as spaces for creating and negotiating relationships with peers, as well as previous research that has analyzed mobile phone use among family members [44]. Omani students responded differently: $41 \%$ (35\% of male and $45 \%$ of female students) reported using their phones to connect with their professors. As mentioned, the percentage of Omani students $(72 \%$ total) reporting using the mobile phone to connect with friends of the opposite sex was unexpectedly high, given the cultural context. It is noteworthy that in an Islamic culture where boundaries between genders and hierarchies between professors and students are clearly marked, young people, especially women, reported using their mobile phones to communicate with opposite-sex friends and their professors. This suggests that the mobile phone, as a cultural tool, is both indexing and promoting cultural change (see [45] for a discussion of how Omani educators use WhatsApp to propel social change). Moreover, Omani students ( $40 \%$ of male and $60 \%$ of female students) indicate that mobile phones improve their access to their professors (Figure 1). 


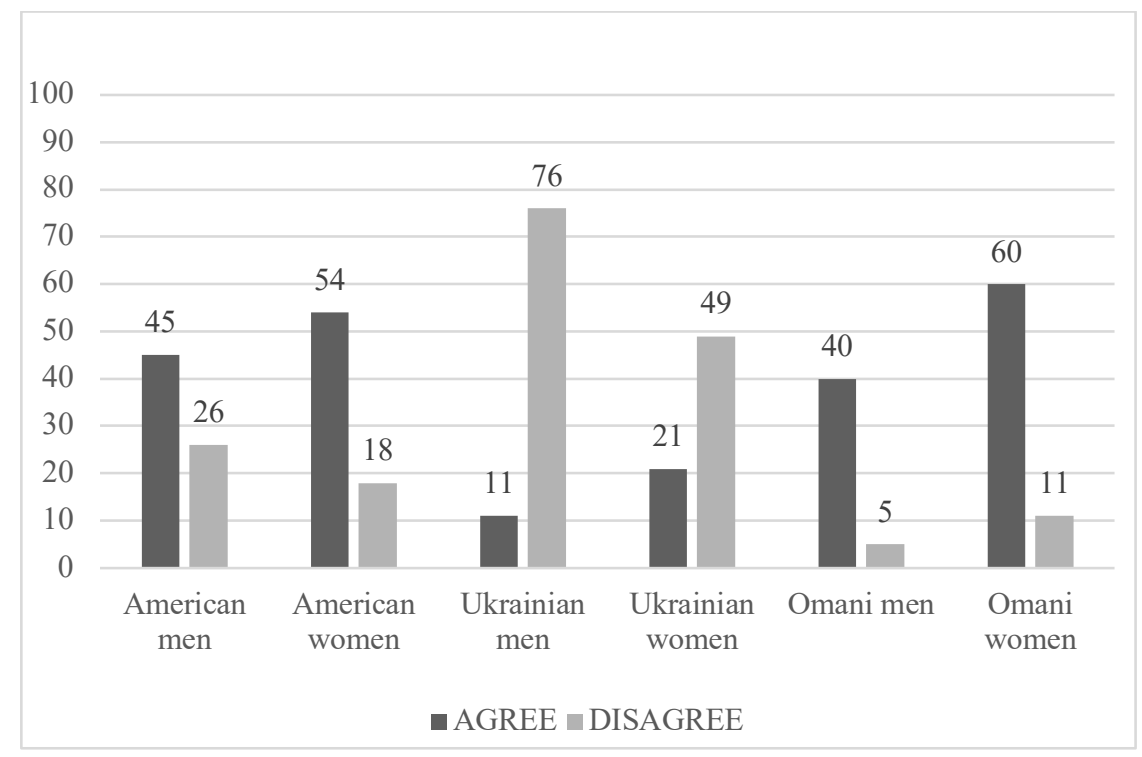

Fig. 1. Student responses to "Mobile phones improve my access to my professors," by percentage

While American students did not view the mobile phone as a way to connect with professors (see Table 2), many ( $45 \%$ of the men and $54 \%$ of the women) agreed with the statement "Mobile phones improve my access to professors, as shown in Figure 1. There are some tentative gender patterns of interest here too: A higher percentage of women than men agreed with this statement, and a higher percentage of men disagreed. In contrast to American and Omani students, Ukrainian students did not believe that their mobile phones improved their access to professors; as Figure 1 shows, $49 \%$ of the female and $76 \%$ the male students in the Ukrainian data subset disagreed with this statement. This finding can be explained by the relatively low number of Ukrainian students who at the time of the data collection owned the latest models of mobile phones; only $36 \%$ of them reported owning smartphones at all. Therefore, unlike their American and Omani peers, Ukrainian students had limited access to their professors via their phones, being unable to send or receive email messages, because their phones did not have that affordance. At the same time, a number of Ukrainian students $(42 \%$ of the women and $30 \%$ of the men) believed that students and their professors should exchange mobile phone numbers to stay in contact (see Figure 2). This is perhaps indicative of how Ukrainian culture straddles collectivist (valuing sharing) and individualist (prizing independence) orientations (see [6] for a discussion). 


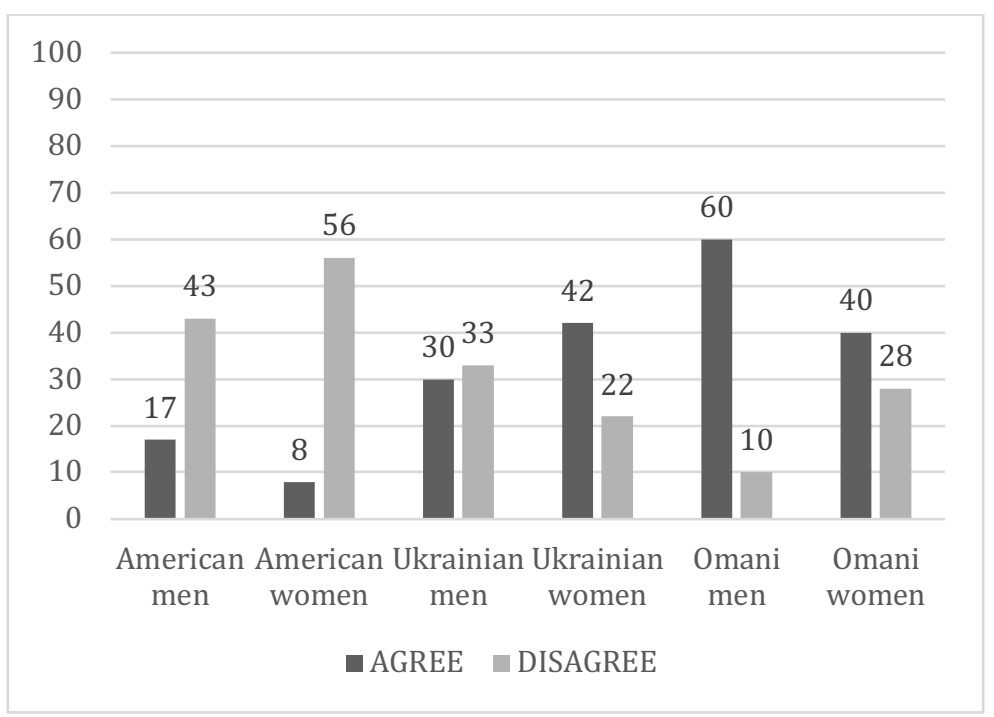

Fig. 2. Student responses to "Professors and students should exchange mobile phone numbers so they can stay in contact," by percentage

Among Omani students the percentage who agreed with the statement that "Professors and students should exchange mobile phone numbers so they can stay in contact" was even higher than among Ukrainian students: $60 \%$ of male and $40 \%$ of female students. Al Zidjaly, from ethnographic observations and experience as an educator, confirms that student-professor phone number exchanges have become a common practice in Oman, a more communal, collectivist culture. Additionally, as mentioned, mobile phones give Omani students new means of breaking with traditions, including interacting in more informal ways with professors. Moreover, Al Zidjaly's experience at the university suggests that mobile phones offer a less face-threatening way, perhaps especially for male students, to seek assistance than asking questions in class or attending in-person office hours.

A rather different picture emerged in the American subset: Just over 11\% of American students $(17 \%$ of the men and $8 \%$ of the women) agreed, while $52 \%(43 \%$ of the men and $56 \%$ of the women) disagreed with the idea of student-professor phone number exchanges. Quite a few of them chose "neither agree nor disagree" with this statement, perhaps as a result of this being an unfamiliar practice (indeed Gordon was very surprised to learn of this practice in Oman). Figure 2 shows that the American women were less likely to indicate that students and professors should exchange mobile phone numbers (only $8 \%$ of them agreed; $56 \%$ disagreed). These findings can be interpreted within the complex cultural discourses that circulate in the United States. At the time of data collection, mobile phones were marketed in the U.S. as means of connecting with family and friends (not professors) and for social (not academic) functions, and this cultural discourse is reflected in students' responses. For example, consider the "Framily plan" offered in 2015 (the year after data collection ended) by the mobile service provider Sprint and described as a "friends and family program, in 
which the discount increases with each additional member" (The plan's family orientation is described and confirmed by an online blogger [46]). This conceptualizes family and friends as an immediate network of connections. Moreover, in the American context, professor/student relationships have traditionally been fraught with murky boundaries. Academic research on "boundary dilemmas" in faculty/student interactions and relationships (e.g., [47], as well as their depictions in popular culture, includes a number of cases of (usually male) professors take advantage of their power over (usually female) students. For example, Flaherty [48] observes, "The intellectual and physical seduction of young female students by older, male professors [...] is so common in movies and books that it's become a cliché." Thus, American cultural discourses frame mobile phones and other forms of new media as problematic for professor/student as well as teacher/student relationships. A 2013 article in Family Circle magazine (now Family Covers) with the title "Is Social Media Causing Inappropriate Teacher-Student Relationships?" begins "Cell phones, texting and Facebook are hot new tools in the classroom, but there's a growing concern that tech has brought students and teachers too close for comfort" [49]. All this points to the view that personal technology, especially mobile phones, in educational contexts, is in some ways something to be feared, and - in our study - American women's greater disagreement that professors and students should exchange mobile phone numbers can be seen as one outcome of this discourse.

Ukrainian cultural discourses at that time of data collection were pointing to a different type of fear, a fear of dependence on modern technology which was the recurrent theme in a number of popular articles for and about young people. The warning "Remember, you should benefit from modern technologies, but you should not be dependent on them!" in an online magazine for youth Molodi.In.UA [50] summarizes these cultural discourses. Simultaneously, like in the United States, mobile phones in Ukraine were also understood as productive tools to connect with family; that the advertisements of Kyivstar and MTS (the two largest mobile service providers in Ukraine) were filled with depictions of families support this claim. Thus, Ukrainian students' answers to our questionnaire are situated in the cultural discourses of privileging the use of mobile phones for staying in touch with family and apprehension of the (over)reliance on, or even addiction to, modern technology.

In Oman, the cultural discourses around mobile phones are nested within the larger discourse of tension between tradition and change. Specifically, when our surveys were conducted, the prevalent messages in Omani media (print and TV) were filled with fear that mobile phones might be changing the essence of Omani traditions. The images on the website of Omantel - the sole provider of the mobile technology, thus with acute awareness of how Omanis use their mobile phones - at the time serve as illustrations. For instance, one image depicts a nuclear family of four holding hands against the blue sky with a teenage daughter in Omani traditional clothes in the foreground. The daughter is trying to break free from her family, and perhaps tradition, with a raised fist and a smile, while her father, also smiling, tries to keep her connected to the family by holding her hand. This image aptly demonstrates that despite efforts to maintain traditions, change is inevitable. Namely, mobile phones literally and symbolically take young people, especially young women, outside the confines of 
their homes and allow them to establish relationships beyond family circles. These cultural discourses, at least in part, explain why Omani students, especially female students, indicate that they - in breaking with tradition - use mobile phones to connect with their friends of the opposite sex and their professors.

The foregoing discussion emphasized the importance of collecting ethnographic observations and other types of data to complement self-reports but also, and more importantly, showed that it is necessary to situate interpretation of such findings in the context of circulating cultural discourses. In the next section, we turn to the analysis of the reported use of mobile phones in the classroom setting specifically.

\subsection{Mobile phones in classroom settings}

As discussed, cultural discourses appear to shape how students view their mobile phones as means of connection to others, including professors. The issue of mobile phones in the classroom also merits exploration. Our analysis shows that overall more American (65\% male and 43\% female) and Omani ( $72 \%$ male and $60 \%$ female) students than Ukrainian (16\% male and 41\% female) students reported using their mobile phones during class to find course-related information (Figure 3 ).

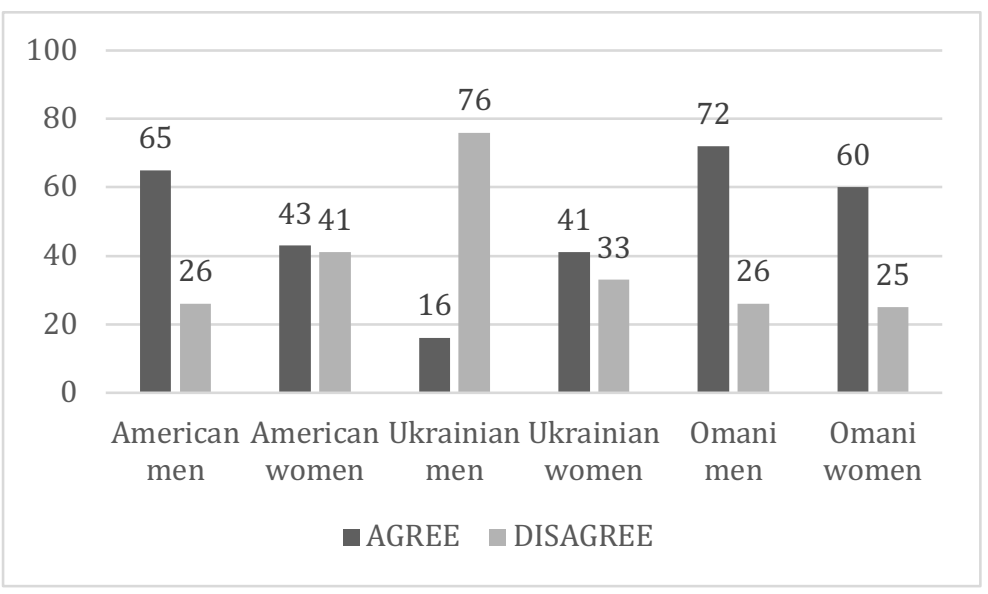

Fig. 3. Student responses to "I have used my mobile phone during class to find information related to course material," by percentage

Interestingly and somewhat surprisingly, a similar pattern, the exact pattern of agreement in the case of the American data subset, emerged in the students' responses to the question about using a mobile phone during class to keep oneself entertained: Overall more American students (65\% male and 43\% female) and Omani students (42\% male and 38\% female) reported using their mobile phones during class as a means of entertainment, in contrast to the Ukrainian students (9\% male and $27 \%$ female) (Figure 4). 


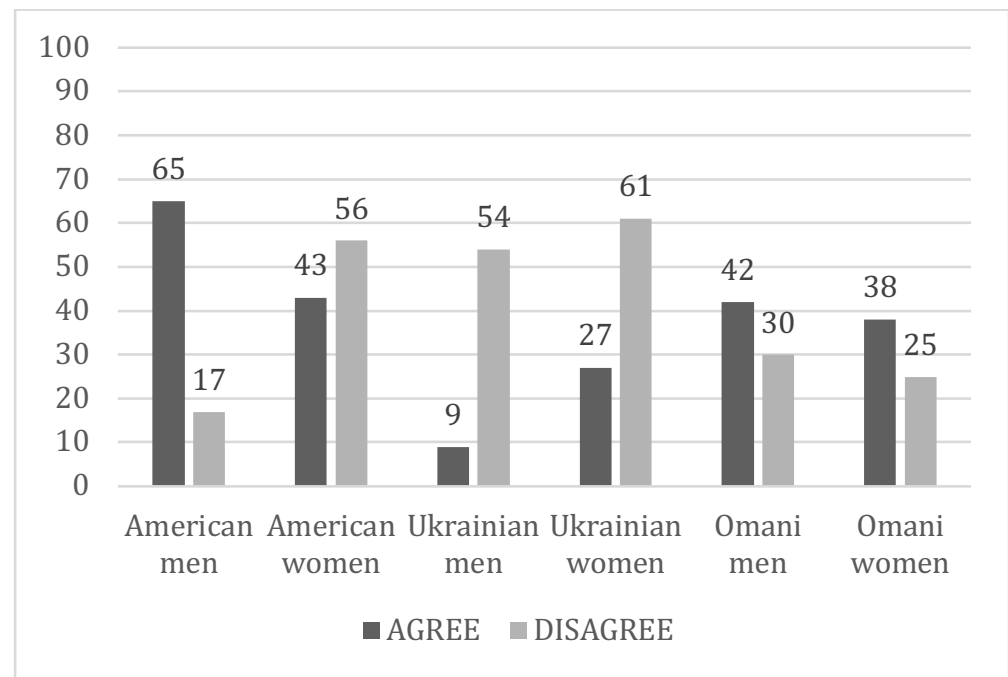

Fig. 4. Student responses to "I have used my mobile phone during class to keep myself entertained," by percentage

Figures 3 and 4 show that more of the American college men than women $(65 \%$ versus $43 \%$ ) reported using their mobile phones both for learning purposes and activities unrelated to course content (e.g., texting, entertainment). Yet, only 30\% of American men and $31 \%$ of women agreed that "Professors should treat mobile phones as educational tools." Most American students however (just over 50\% for both women and men), neither agreed nor disagreed with this statement, and only $5 \%$ of them agreed with a statement suggesting that phones should be banned from classrooms.

In fact, the vast majority of students, across the three cultural contexts, were against banning mobile phones in classrooms; this is in line with prior research (e.g., $[11,15])$ that suggests that many young people cannot imagine their lives without their phones. It is still unclear if the American students were ready to consider phones as educational tools (even if they did not want them removed from class). In the context of Ukraine, an interesting finding is that more female than male students ( $41 \%$ to $16 \%$ ) indicated that they used their mobile phones to find class-related information during class. This is the reverse of the pattern that emerged in the American and Omani data subsets. Related, more female Ukrainian students (23\% to $17 \%)$ agreed that "Professors should treat mobile phones as educational tools," and with an item identifying mobile phones as useful tools in college classroom (37\% to $28 \%$ ). These findings can be connected to a previous finding [6]: More female than male Ukrainian students reported having smart phones with more advanced capabilities, including information retrieval. This underscores the importance of the "technical" side of the mobile phone as a cultural tool and shows that professors should also take into consideration their students' varied access to technology. Similar to the American students, although not as overwhelmingly, the minority of Ukrainian students $(17 \%$ men and $22 \%$ women) reported wanting mobile phones to be banned from classes. This suggests that while Ukrainian students' phones were not as advanced as the phones of 
their American and Omani counterparts, they still were valued as something to be maintained in one's possession.

Compared to the American and Ukrainian students, more Omani students $(72 \%$ men and $60 \%$ women) reported using mobile phones as educational tools. These numbers also surpassed how many Omani students reported using their phones as a means of entertainment during class ( $42 \%$ men and $38 \%$ women). For the statement "Professors should treat mobile phones as educational tools," $58 \%$ of male and $42 \%$ of female Omani students agreed. This fits with our other findings indicating the Omani students' willingness to engage with professors and educational materials on their phones. However, in contrast to Ukrainian and especially American students who did not want mobile phones to be banned from classrooms, a rather high percentage of Omani students (44\% men and $40 \%$ women) agreed that "Mobile phones should be banned in college classrooms." At the same time, an almost equal number of Omani students ( $42 \%$ men and $33 \%$ women) disagreed with this statement, thus pointing to the ambivalent role the mobile phone plays in the classroom setting: It is both a means of accessing educational information and distracting from the education process.

\section{$5 \quad$ Implications and Limitations}

Our findings reveal how, as cultural tools, mobile phones are understood and used differently by college students in different cultural contexts, while also identifying gender differences. This is important to keep in mind in educational as well as general settings, given the diverse nature of our colleges and universities and cultural practices in general. We propose that the cultural tool perspective helps illuminate how - and explain why - the mobile phone is not "the same" tool for all users. Instead, culture, with its many facets, shapes how people utilize and perceive their mobile phones.

Understanding this could help keep intercultural and cross-cultural miscommunication at bay. For example, it is not hard to imagine how surprised an American student studying in Oman might be when asked to exchange mobile phone numbers with a professor, or how neglected an Omani student might feel in the U.S. when such information is not exchanged. At the same time, knowing how to utilize mobile phones to their fullest and to understand the agency, creativity, and attitudes of their users can have positive outcomes in terms of teaching and learning. For instance, based on our dataset, we were able to discern that Omani students, both male and female, appear to be more comfortable, as compared to their American and Ukrainian peers, using mobile phones to connect with their professors and as educational tools in classroom settings. A recent study from Oman [51] and a cross-cultural investigation that surveyed students from Qatar and the United States [52] confirm that Middle Eastern students appear to be more accepting, if not welcoming, of mobile phones as educational tools and of m-learning in general than their peers in Western countries, the United States in particular. All this allows us to suggest that in implementing mtechnology, such as mobile phone-based learning applications, educators need to consider not only the immediate context of a classroom but also, and with regularity, 
the circulating cultural discourses. Noticing cultural changes regarding technologies, and social issues, may lend insights into classroom interactions and approaches to teaching and learning. For instance, as our data analysis indicates, young Omani women's uses of their mobile phones reflect and construct a shift in Omani culture that challenges traditional gender roles and behaviors. In this regard, and as we argue above, it is productive to view technologies not as neutral devices but as cultural tools with their affordances and limitations. Cultural tools are thus, borrowing from Tannen's [53] work on linguistic strategies, polysemous and ambiguous: The same technology, such as mobile phones, can be used to engage in and/or to distract from academic work in the classroom. Our study shows that students across all cultural groups reported (though to different extents) that they use their mobile phones for educational and entertainment purposes in class, aligning with recent studies in Qatar [11] and Russia [12]. Godwin-Jones [13] observes that the increased affordability and pervasiveness of smartphones make them essential tools in mobile-assisted learning; however, we add, educators need to be also aware that the same qualities (affordability and pervasiveness) make smartphones equally attractive tools of distraction from learning, and further that there are accessibility issues for some students.

While this study offers a window into undergraduate students' perceptions of mobile phones in Ukraine, Oman, and the United States, it has limitations. First, the data were collected several years ago and may not, indeed likely do not, fully represent today's practices. However, this speaks to our very point: Mobile phones are cultural tools, and their contexts of use change over time, situated not only in (national) culture, but also in the state of technology (e.g., smartphones becoming more widespread) and normative practices (e.g., teaching face-to-face versus online). The snapshot our study provides can be used as a touchstone for future analyses of students' perceptions and reported uses of mobile phones for learning purposes. Second, our data are convenience samples collected in three rather different universities, and, thus, are likely not representative of all first-year students in the three countries. Furthermore, even though the higher number of female participants correlate with the overall higher percentage of female students in the humanities and social sciences, the rather small number of male participants, especially in the Ukrainian data subset, might have affected the reported results of the study. Additionally, the continuum and fluidity of gender identification, as well as sexual orientation, were not considered nor were the race/ethnicity of the participants. Finally, although we constructed the questionnaire based on prior studies and our ethnographic observations, our data, like all self-reports (see [34] for a discussion), contain accounts of behavior that may or may not match actual practices. Therefore, to gain a more nuanced understanding of how, when, and why students, and professors, use mobile phones, future studies should focus on detailed, ethnographically based case studies. Such studies are of increased importance, and even urgency, given the current state of accomplishing education with very little to no face-to-face interaction between students and professors. 


\section{Conclusion}

Our study provides a glimpse into students' perceptions of mobile phones in Ukraine, Oman, and the United States and indicates that students' beliefs about and uses of mobile phones are shaped by cultural discourses, or understandings of personhood, relationships, and communication. We thus suggest that mobile phones in educational settings are productively understood, and should be treated as, cultural tools rather than neutral technological artifacts. For example, in Oman, professors should consider increasing the incorporation of mobile phones as educational tools, as many students are reportedly interested in and familiar with this practice and believe mobile phones to be a good way of connecting with professors. In Ukraine and the United States, the data so far suggest that students have mixed perspectives about phones as educational tools, and students generally do not want to connect with professors through their mobile phones, which they view more as tools for social engagement, such as with family and friends. We suspect, however, that the pandemic may very well be altering these perspectives. Additionally, our work shows that in all three cultures there are gender differences in how students report using and orienting to their mobile phones that merit further consideration. We believe that considering mobile phones as cultural tools, and as related to cultural discourses, adds to our understanding of mobile phone use in education-related communication. As our cultural discourses and practices change - in response to COVID or other global and local events - it is crucial to acknowledge the ways in which the meanings of communication technologies are shaped by their users, and how this in turn influences their uses in education.

\section{$7 \quad$ Acknowledgement}

Research in Oman was carried out as part of an ethnographic project funded by Sultan Qaboos University in Oman: The Impact of Social Media on Omani Youth: A Multimodal Project (SR/ART/ENGL/15/01) - Najma Al Zidjaly, PI.

\section{References}

[1] R. Scollon, Mediated Discourse. The Nexus of Practice. London and New York: Routledge, 2001.

[2] D. Carbaugh, Talking American: Cultural Discourses on Donahue. Norwood: Ablex, 1988.

[3] C. C. Tossell, P. Kortum, C. Shepard, A. Rahmati, and L. Zhong, "You can lead a horse to water but you cannot make him learn: Smartphone use in higher education," British Journal of Educational Technology, vol. 46, no. 2, pp. 713-724, 2015. https://doi.org/10.1111/ bjet.12176

[4] International Telecommunication Union, "Measuring digital facts and figures 2020," 2020. [Online]. Available: https://www.itu.int/en/ITU-D/Statistics/Documents/facts/FactsFigures 2020.pdf [Accessed Jan. 26, 2021]. 
[5] N. Al Zidjaly and C. Gordon, "Mobile phones as cultural tools: An Arabian example," Intercultural Management Quarterly, vol. 13, no. 2, pp. 14-17, 2012.

[6] C. Gordon, N. Al Zidjaly, and A. Tovares, "Mobile phones as cultural tools among college students in Oman, Ukraine, and the U.S.," Discourse, Context \& Media, vol. 17, pp. 9-19, 2017. https://doi.org/10.1016/i.dcm.2017.01.006

[7] J. A. Hussain, K. Al-Qudah, and R. Al Matari, "Students' attitudes in colleges of education at the Jordanian universities towards mobile phone usage in university education," International Journal of Interactive Mobile Technologies (iJIM), vol. 7, no. 2, 2013. [Online serial.] Available: https://www.online-journals.org/index.php/i-jim/article/view/2286/2562 [Accessed Jan. 26, 2021.)

[8] N. Roberts and M. Rees, "Student use of mobile devices in university lectures," Australasian Journal of Educational Technology, vol. 30, no. 4, pp. 415-426, 2014.

[9] M. M. The, "Investigations of students' mobile phone usage and influences towards their mobile learning adoption: A case study in Myanmar," International Journal of Interactive Mobile Technologies (iJIM), vol. 12, no. 5, 2018. [Online serial.] Available: https://www. online-journals.org/index.php/i-jim/article/view/8924/5167. [Accessed Jan. 26, 2021]. https://doi.org/10.3991/ijim.v12i5.8924

[10] S. A. Ariffin, C. Glahn, M. Anshar, F. Daud, T. T. Kiong, N. H. Noordin, and A. Kamsin, "Early investigation of the impact of mobile learning ethics student-generated activities for STEM subjects in a local Malaysian university context," International Journal of Interactive Mobile Technologies (iJIM), vol. 14, no. 5, 2020. [Online serial.] Available: https://www.online-journals.org/index.php/i-jim/article/view/13359/6777. [Accessed Jan. 26, 2021]. https://doi.org/10.3991/ijim.v14i05.13359

[11] B. Al Fakih, A. Morei, and M. Salehi, "Student impression about using mobile phones in classroom," International Journal of Emerging Technologies in Language (iJET), vol. 15 no. 22, 2020. [Online serial.] Available: https://online-journals.org/index.php/i-jet/article/ view/16219 [Accessed Jan. 24, 2021]. https://doi.org/10.3991/ijet.v15i22.16219

[12] V. Tugun, A. R. Bayanova, K. G. Erdyneeva, N. A. Mashkin, Z. M. Sakhipova, L. V. Zasova, "The opinions of technology supported education of university students," International Journal of Emerging Technologies in Learning (iJET), vol. 15, no. 23, 2020. [Online serial]. Available: https://online-journals.org/index.php/i-jet/article/view/18779 [Accessed Jan. 10, 2021]. https://doi.org/10.3991/ijet.v15i23.18779

[13] R. Godwin-Jones, "Emerging technologies: Web-writing 2.0: Enabling, documenting, and assessing writing online," Language Learning \& Technology, vol. 12, no. 2, pp. 7-13, 2008.

[14] J. Gikas and M. M. Grant, "Mobile computing devices in higher education: Student perspectives on learning with cellphones, smartphones \& social media," Internet and Higher Education, vol. 19, pp. 18-26, 2013. https://doi.org/10.1016/j.iheduc.2013.06.002

[15] J. Keengwe, G. Schnellert, and D. Jonas, "Mobile phones in education: Challenges and opportunities for learning," Education and Information Technologies, vol. 19, no. 2, pp. 441-450, 2014. https://doi.org/10.1007/s10639-012-9235-7

[16] A. A. Economides and N. Nikolaou, "Evaluation of handheld devices for mobile learning," International Journal of Engineering Education, vol. 24, no. 1, pp. 3-13, 2008.

[17] B. Gupta and Y. Koo, "Applications of mobile learning in higher education: An empirical study," International Journal of Information and Communication Technology Education, vol. 6, no. 3, pp. 75-87, 2010. https://doi.org/10.4018/jicte.2010070107

[18] M. Masrom and I. Zuraini, "Benefits and barriers to the use of mobile learning in education: Review of literature," in Mobile Learning: Pilot Projects and Initiatives, R. Guy, Ed. Santa Rosa: Informing Science Press, 2010, pp. 9-26. 
[19] B. Williamson, R. Eynon, and J. Potter, "Pandemic politics, pedagogies and practices: Digital technologies and distance education during the coronavirus emergency," Learning, Media and Technology, vol. 45, no. 2, pp. 107-114, 2020. https://doi.org/10.1080/17439 884.2020 .1761641

[20] R. Junco and S. Cotton, "No A 4 U: The relationship between multitasking and academic performance," Computers \& Education, vol. 59, no. 3, pp. 505-514, 2012. https://doi.org/ 10.1016/j.compedu.2011.12.023

[21] L. D. Rosen, A. F. Lim, L. M. Carrier, and N. Cheever, "An empirical examination of the educational impact of text message-induced task switching in the classroom: Educational implications and strategies to enhance learning," Psicologia Educativa, vol. 17, no. 2, pp. 163-177, 2011. [Online serial.] Available: https://doi.org/10.5093/ed2011v17n2a4 [Accessed Jan. 26, 2021]. https://doi.org/10.5093/ed2011v17n2a4

[22] J. E. Katz, Ed., Magic in the Air: Mobile Communication and the Transformation of Social Life. New Brunswick: Transaction Publishers, 2006.

[23] M. Chan, "Mobile phones and the good life: Examining the relationships among mobile use, social capital and subjective well-being," New Media \& Society, vol. 17, no. 1, pp. 96113, 2015. https://doi.org/10.1177/1461444813516836

[24] V. Oksman and P. Rautiainen, "Perhaps it is a body part': How the mobile phone became an organic part of the everyday lives of Finnish children and teenagers," in Machines that Become Us: The Social Context of Personal Communication Technology, J. E. Katz, Ed. New Brunswick: Transaction Publishers, 2003, pp. 293-308. https://doi.org/10.4324/ 9780203786826-22

[25] J. A. Roberts, L. H. P. Yaya, and C. Manolis, "The invisible addiction: Cell-phone activities and addiction among male and female college students," Journal of Behavioral Addictions, vol. 3, no. 4, pp. 254-265, 2014. https://doi.org/10.1556/jba.3.2014.015

[26] A. Black, "Gen Y: Who they are and how they learn," Educational Horizons, vol. 88, no. 2, pp. 92-101, 2010. [Online serial]. Available: https://eric.ed.gov/?id=EJ872487. [Accessed Jan. 25, 2021].

[27] M. Kearney, S. Schuck, K. Burden, K., and P. Aubusson, "Viewing mobile learning from a pedagogical perspective," Research in Learning Technology, vol. 20, no. 1, 2012. [Online serial]. Available: https://doi.org/10.3402/rlt.v20i0.14406 [Accessed Jan. 26, 2021].

[28] A. Domínguez, J. Saenz-de-Navarrete, L. De-Marcos, L. Fernández-Sanz, C. Pagés, C., and J-J. Martínez-Herráiz, "Gamifying learning experiences: Practical implications and outcomes," Computers \& Education, vol. 63, pp. 380-392, 2013. https://doi.org/10.1016/ j.compedu.2012.12.020

[29] A. Aljaloud, N. Gromik, P. Kwan, and W. Billingsley, "Saudi undergraduate student's perceptions of the use of smartphone clicker apps on learning performance," Australasian Journal of Educational Technology, vol. 35, no. 1, pp. 85-99, 2019. https://doi.org/10.147 42/ajet.3340

[30] S. N. Sad and Ö. Göktas, "Preservice teachers' perceptions about using mobile phones and laptops in education as mobile learning tools," British Journal of Educational Technology, vol. 45, no. 4, pp. 606-618, 2014. https://doi.org/10.1111/bjet.12064

[31] B. W. O'Bannon and K. Thomas, "Teacher perceptions of using mobile phones in the classroom: Age matters!” Computers \& Education, 74, 15-25, 2014. https://doi.org/10.101 6/j.compedu.2014.01.006

[32] L. Corrin, L. Lockyer, and S. Bennett, "Technological diversity: An investigation of students' technology use in everyday life and academic study," Learning, Media and Technology, vol. 35, no. 4, pp. 387-401, 2010. https://doi.org/10.1080/17439884.2010.531024 
[33] F. Nami, "Educational smartphone apps for language learning in higher education: Students' choices and perceptions," Australasian Journal of Educational Technology, vol. 36, no. 4, pp. 82-95, 2020. https://doi.org/10.14742/ajet.5350

[34] S. P. Walsh, K. M. White, and R. M. Young, "Needing to connect: The effect of self and others on young people's involvement with their mobile phones," Australian Journal of Psychology, vol. 62, no. 4, pp. 194-203, 2010. https://doi.org/10.1080/000495309035672 $\underline{29}$

[35] M. Haverila, "Cell phone usage and broad feature preferences: A study among Finnish undergraduate students," Telematics and Informatics, vol. 30, pp. 177-188, 2013. https://doi. org/10.1016/j.tele.2012.05.002

[36] R. Toor, "Turns out you can build community in a zoom classroom," The Chronicle of Higher Education, 2020, June 23. [Online]. Available: https://www.chronicle.com/article/Turns-Out-You-Can-Build/249038 [Accessed Jan. 25, 2021]

[37] R. Schroeder, “Are you a victim of zoom fatigue?” Inside Higher Education, 2020, May 6. [Online]. Available: https://www.insidehighered.com/digital-learning/blogs/onlinetrending-now/are-you-victim-zoom-fatigue [Accessed Jan. 26, 2021]

[38] D. Batty, "Harassment fears as students post extreme pornography in online lectures," The Guardian, April 22, 2020. [Online]. Available: https:/www.theguardian.com/education/ 2020/apr/22/students-zoombomb-online-lectures-with-extreme-pornography [Accessed Jan 26, 2021]

[39] I. Kogut, 2014, “Чим відрізняються жінки і чоловіки: про гендерну (не)рівність у вищій освіті" ("How men and women differ: On gender (in)equality in higher education"), CEDOS, 2014, July 10. Available: https://cedos.org.ua/uk/articles/chym-vidrizniaiutsiazhinky-i-choloviky-pro-hendernu-ne-rivnist-u-vyshchii-osviti. [Accessed Jan. 26, 2020]

[40] N. S. Baron and E. M. Campbell, "Gender and mobile phones in cross-national context," Language Sciences, vol. 34, pp. 13-27, 2012. https://doi.org/10.1016/j.langsci.2011.06.018

[41] G. Bell, "The age of the thumb: A cultural reading of mobile technologies from Asia," Knowledge, Technology \& Policy, vol. 19, no. 2, pp. 41-57, 2006. https://doi.org/10. 1007/s12130-006-1023-5

[42] I. Gershon, The Breakup 2.0: Disconnecting over New Media. Ithaca, NY: Cornell University Press, 2012.

[43] K. Davies, "Friendship 2.0: Adolescents' experiences of belonging and self-disclosure online," Journal of Adolescence, vol. 35, no. 6, pp. 1527-1536, 2012. https://doi.org/10. 1016/j.adolescence.2012.02.013

[44] K. Hertlein, "Digital dwelling: Technology in couple and family relationships," Family Relations, vol. 61, no. 3, pp. 374-387, 2012. https://doi.org/10.1111/j.17413729.2012.00702.x

[45] N. Al Zidjaly, "WhatsApp Omani teachers? Social media and the question of social change," Multimodal Communication, vol. 3, no. 1, pp. 107-130, 2014. https://doi.org/10.1515/mc-2014-0007

[46] R. Cheng, "Framily's a hit? Sprint CEO calls it fastest growing plan ever," CNET, Apr. 29, 2014 [Online]. Available: http://www.cnet.com/news/framilys-a-hit-sprint-ceo-calls-itfastest-growing-plan-ever/ [Accessed: Jan. 26, 2021]

[47] L. P. Aultman, M. R. Williams-Johnson, and P. A. Schutz, "Boundary dilemmas in teacher-student relationships: Struggling with 'the line'," Teaching and Teacher Education, vol. 25, no. 5, pp. 636-646, 2009. https://doi.org/10.1016/j.tate.2008.10.002

[48] C. Flaherty, "Wanted: Adoring female students. Do male professors need and seek out attention from their female students?" Slate, Oct. 13, 2013. [Online]. Available: https://slate. 
com/human-interest/2013/10/male-professors-female-students-a-tricky-power-dynamic. html. https://doi.org/10.3758/bf03335007

[49] R. Laliberte, "Inappropriate teacher-student relationships?” Family Covers, Nov. 2013. [Online]. Available: https://www.familycovers.com/teen/school/issues/teacher-studentrelationships-social-media/index.html

[50] T. Semeniuk, “Мобільний телефон-невід’ємна частина життя” (Mobile phone-an integral part of life," Molodi.In.UA, Oct. 21, 2010. Available: http://molodi.in.ua/mobilnyjtelefon-nevidjemna-chastyna-zhyttya/ [Accessed Jan. 26, 2020]

[51] S. K. Sharma, M. Sarrab, and H. Al-Shihi, "Development and validation of mobile learning acceptance measure," Interactive Learning Environments, vol. 25, no. 7, pp. 847-858, 2017. https://doi.org/10.1080/10494820.2016.1224250

[52] M. El-Masri and A. Tarhini, "Factors affecting the adoption of e-learning systems in Qatar and USA: Extending the unified theory of acceptance and use of technology 2 (UTAUT2)," Educational Technology Research and Development, vol. 65, pp. 743-763, 2017. https://doi.org/10.1007/s11423-016-9508-8

[53] D. Tannen, Gender and Discourse, New York: Oxford University Press, 1994.

\section{Authors}

Alla V. Tovares is Associate Professor in the Department of English at Howard University. Her research interests include Bakhtin's theory of dialogue and carnival, language ideologies, and online communication. She is the co-author (with Raúl Tovares) of How to Write about the Media Today (ABC-CLIO, 2010) and co-editor (with Cynthia Gordon) of Identity and Ideology in Digital Food Discourse (Bloomsbury, 2020); her recent articles have appeared in Discourse, Context \& Media; World Englishes; Discourse \& Society; and Multilingua.

Cynthia Gordon is Associate Professor in the Department of Linguistics at Georgetown University. Her research interests include interactional sociolinguistics; discourse in family, health-related, and digital contexts; and intertextuality and metadiscourse. She is author of Making Meanings, Creating Family (Oxford University Press, 2009) and co-editor (with Alla Tovares) of Identity and Ideology in Digital Food Discourse (Bloomsbury, 2020). She is on the editorial boards of Language in Society, Journal of Sociolinguistics, and Journal of Language and Social Psychology.

Najma Al Zidjaly is Associate Professor in the Department of English Language and Literature at Sultan Qaboos University. She is the author of Disability, Discourse and Technology: Agency and Inclusion in (Inter)action (Palgrave Macmillan, 2015) and the editor of the special issue "Society in Digital Contexts: New Modes of Identity and Community Construction" (Multilingua, 2019). Her research focuses on social media and Arab (Omani) identity. She serves on the editorial board of the Journal of Multimodal Communication; her articles have been published in Language in Society; Discourse \& Society; Discourse, Context \& Media; and Visual Communication.

Article submitted 2021-02-04. Resubmitted 2021-03-16. Final acceptance 2021-03-17. Final version published as submitted by the authors. 